\title{
Zinc oxide (ZnO) induced toxicity and behavioural changes to oligochaete worm Tubifex tubifex (Muller)
}

\author{
Arnab Chatterjee ${ }^{1}$, Ritwick Bhattacharya ${ }^{1}$, Nimai Chandra Saha ${ }^{1 *}$ \\ ${ }^{1}$ Fishery and Ecotoxicology Research Laboratory (Vice-Chancellor's Research Group), Department of Zoology, The \\ University of Burdwan, Burdwan 713104, West Bengal, India \\ *Corresponding author's e-mail: research.ncsaha@gmail.com
}

Available online at: www.isroset.org

Received: 01/Apr/2019, Accepted: 14/Apr/2019, Online: 30/Apr/2019

\begin{abstract}
Zinc is among the important trace element of the body by participating in several biological processes. But it shows toxicity after a certain concentration. Zinc oxide $(\mathrm{ZnO})$, a hazardous heavy metal, is frequently used in both bulk and nanoparticle format in industrial and household purposes throughout India. In the present study the 24, 48, 72 and $96 \mathrm{~h} \mathrm{LC}_{50}$ values of $\mathrm{ZnO}$ was monitored to benthic oligochaete worm Tubifex tubifex (Muller) through Finney's probit analysis method. Different abnormal behavioural changes in the worm were also recorded during the exposure period. The 24, 48, 72 and 96h $\mathrm{LC}_{50}$ values of Zinc oxide $(\mathrm{ZnO})$ to Tubifex tubifex was obtained as $30.88,24.15,19.95$ and $11.15 \mathrm{mg} / \mathrm{l}$ respectively. The mortality rate of Tubifex tubifex varied significantly $(\mathrm{p}<0.05)$ with a dose and time dependent manner $(24,48,72$ and $96 \mathrm{~h})$. The exposed worm showed several erratic behaviors with the gradually increasing concentrations of the metal and with the progress of time of exposure. The safe concentration of this metal was ranged between $0.0001115-1.11 \mathrm{mg} / \mathrm{l}$. Based on $96 \mathrm{~h}$ $\mathrm{LC}_{50}$ value the Maximum allowable concentration (MAC), no observable effect concentration (NOEC) and the lowest observable effect concentration (LOEC) of Zinc oxide to Tubifex tubifex were 1.11, 1.3 and $2.1 \mathrm{mg} / \mathrm{l}$ respectively. The present study will be useful in determination of the safe dose of the toxicant before its disposal to the environment.
\end{abstract}

Keywords: Zinc, Acute toxicity, $L C_{50}$, Tubifex tubifex, behavioural response.

\section{INTRODUCTION}

In the recent decade, the increasing water pollution causes a great threat to aquatic environment including the aquatic life. The heavy metal pollution causes a serious health problem for the aquatic organisms. Toxicants like heavy metals, pesticides reach the aquatic bodies through industrial and agricultural runoffs. [1]. Increased heavy metal concentration into water bodies can lead to destruction of natural ecosystem by exposing the organisms to high level of metal toxicity [2]. Aquatic organisms like fish, crustaceans and bottom dweller oligochaete worms are most susceptible to this heavy metal toxicity as they cannot escape from the water bodies [3]. Heavy metal toxicity also has a high risk of bioaccumulation and bio magnification [4].

Among different trace metals of body, Zinc $(\mathrm{Zn})$ is an important one. It has important role in structural formation of protein and act as cofactors of several enzymes [5]. It participates in several biological processes. Zinc oxide $(\mathrm{ZnO})$ and Zinc oxide derived nanoparticles are among the most commonly used nano-material in different fields including medical applications, industrial and household products [6]. Despite being a key trace element of body, after a certain concentration it shows toxicity to exposed organisms. Aquatic organisms are more susceptible to its toxicity [7]. The extensive use of $\mathrm{ZnO}$ leads to their discharge into the aquatic ecosystem. For these reasons, the risk assessment and toxicity evaluation of Zinc oxide has been needed in aquatic toxicology study. The acute toxicity studies on Silver Carp (Hypophthalmichthys molitrix), Grass Carp (Ctenopharyngodon idella), rainbow trout, rainbow trout (Salmo gairdneri) and some other fish have been reported earlier by previous researchers [8-11].

Tubifex tubifex is a freshwater benthic oligochaete worm used as a test organism for sediment bioassay and for determination of acute toxicity of heavy metals and pesticides $[12,13]$. It is a very good bio indicator of pollution as they can survive in areas with heavily polluted organic matter that almost no other species can endure [14]. There are no earlier reports on acute toxicity of $\mathrm{ZnO}$ on Tubifex tubifex. Therefore, in view of the ecological impact of this pesticide, the present study aimed at determination of $\mathrm{LC}_{50}$ of $\mathrm{ZnO}$ to 
the Tubifex tubifex, and their behavioural responses during exposure.

The organization of the paper is as follows, Section I contains the introduction, previous related works and objective of the study, Section II contain the methodologies followed during the work including standard protocols and statistical analysis, Section III contain the results obtained from the study, related tables and figures and the discussion of the work, Section IV concludes research work with future directions.

\section{MATERIALS AND METHODS}

\section{Test animal}

The live specimens of benthic oligochaete worm Tubifex tubifex (Mueller), Phylum: Annelida, Class: Clitellata, Order: Oligochaeta and Family: Naididae, with an average body size of $10.5 \pm 0.5$ mmwere acquired from local fish market and allowed to acclimate in laboratory conditions for 72 hours prior to the experiment. The test organisms were kept in natural and pollution free water (temperature $29.0 \pm 0.4{ }^{\circ} \mathrm{C}$, $\mathrm{pH} 7.2 \pm 0.3$, free $\mathrm{CO}_{2} 13.6 \pm 0.5 \mathrm{mg} / \mathrm{l}$, dissolved oxygen 5.7 $\pm 0.3 \mathrm{mg} / \mathrm{l}$, total alkalinity $182 \pm 8.1 \mathrm{mg} / \mathrm{l}$ as $\mathrm{CaCO}_{3}$, hardness $113 \pm 6.8 \mathrm{mg} / \mathrm{l}$ as $\mathrm{CaCO}_{3}$ ) to determine natural mortality. Physicochemical parameters of water used during experiment were measured as per standard procedure [15]. The photoperiod was kept as per average day and night around 12 hours. Only the healthy organisms were chosen for experiment.

\section{Test chemical}

The heavy metal for the experiment, Zinc oxide $(\mathrm{ZnO})$ was purchased from SRL (51508).Stock solution of the test chemical and its dilutions were made following the standard method [15].

\section{Acute toxicity bioassay}

The acute toxicity test was conducted in a static system to determine the 24, 48, 72 and $96 \mathrm{~h} \mathrm{LC}_{50}$ of $\mathrm{ZnO}$ following the standard guideline [16, 17]. Initially a rough test was conducted to determine the range of the concentrations where mortality occurs. The test organisms were exposed to ten different nominal concentrations $(5,15,30,45,60,75,90$, 100,120 and $140 \mathrm{mg} / \mathrm{l}$ ), along with one control (without test chemical), keeping 10 test organisms in each test concentration in a $250 \mathrm{ml}$ glass beaker having $200 \mathrm{ml}$ of water. No gathering stress was observed during experimentation. Mortality and behavioural changes of test organism were recorded at 24, 48, 72, and $96 \mathrm{~h}$. The dead organisms were removed immediately after their death to avoid any organic decomposition. The investigation was repeated thrice for good statistical significance, following the standard recommendations [18]. Feeding was stopped $24 \mathrm{~h}$ prior to the exposure of toxicant and worms were not fed during the experiment period following the earlier methods $[19,20,21]$. No mortality was observed in the control group of Tubifex tubifex. The behavioural changes (wrinkling effect, clumping tendency, mucus secretion, hyperactive movement and body fragmentation) in the worms were also noted immediately after the exposure to toxicants until the end of experiment as per standard protocol [22, 23].

\section{Statistical Analysis}

All the statistical analysis were done using Graphpad prism and MS-Excel 2016. Finney's probit analysis method [24] was used to calculate the $24,48,72$ and $96 \mathrm{~h} \mathrm{LC}_{50}$ values, which were also subsequently verified following the methods of Miller and Tainter, 1944 [25] and Behrens-Karber method with the help of Klassen formula [26]. Safe concentration of profenofos was calculated following the methods and guidelines of Burdick [27], International Joint Commission (IJC) [28], National Academy of Sciences (NAS/NAE) [29] and Company Wide Quality Control (CWQC) [30] based on the $96 \mathrm{~h} \mathrm{LC}_{50}$ values. Maximum allowable concentration (MAC), no observable effect concentration (NOEC) and the lowest observable effect concentration (LOEC) were also determined.

\section{RESULTS \& DISCUSSION}

The results of percent mortality in different test groups after $96 \mathrm{~h}$ of exposure to $\mathrm{ZnO}$ are shown in Table 1 . No mortality was observed in control worms throughout $96 \mathrm{~h}$. With the increasing concentration of the toxicant, the mortality of the test organism increases. The Lethal concentrations as well as $\mathrm{LC}_{50}$ values for $96 \mathrm{~h}$ along with its $95 \%$ lower and upper confidence limits (ML and MU), slope and intercept of $\mathrm{ZnO}$ as calculated by Finney's probit analysis are shown in Tables 2. The $24,48,72$ and $96 \mathrm{~h} \mathrm{LC}_{50}$ values of $\mathrm{ZnO}$ to Tubifex tubifex were $30.88,24.15,19.95$ and $11.15 \mathrm{mg} / \mathrm{l}$ respectively. The mortality rate of Tubifex tubifex varied significantly $(\mathrm{p}<0.05)$ with increasing exposure times $(24,48$ and 72 and 96h) and doses (2 way ANOVA followed by Tukey test; Table 1, Figure 1). This observation indicated that mortality is dose and time dependent (Figure 2). The $\mathrm{LC}_{50}$ values decreases with the increase in exposure period of the toxicant. It indicates that toxicity of this metal increases with the increase in exposure time.

This $96 \mathrm{~h} \mathrm{LC}_{50}$ value was also assessed and estimated following the methods of Miller and Tainter, 1944 (11.22 $\mathrm{mg} / \mathrm{l}$ ) and Behrens-Karber's method (17.75 mg/l) (Table 3). The three methods are comparable and in good concordance. The safe concentrations calculated for Tubifex tubifex exposed to $\mathrm{ZnO}$ are shown in Table 4 . The safe concentration of $\mathrm{ZnO}$ to Tubifex tubifex ranged between $0.0001115-1.11$ $\mathrm{mg} / \mathrm{l}$ may be considered before their disposal to the natural environment.

Based on computed $\mathrm{LC}_{50} 96 \mathrm{~h}$ on Tubifex tubifex, contaminants MAC value is $1.11 \mathrm{mg} / \mathrm{l}$ for $\mathrm{ZnO}$ in $27 \pm 0.5^{\circ} \mathrm{C}$. In addition, contaminants LOEC were calculated to be 2.1 
$\mathrm{mg} / \mathrm{l}$ for $\mathrm{ZnO}$. NOEC was determined to be $1.3 \mathrm{mg} / \mathrm{l}$ for $\mathrm{ZnO}$ (Table 5).

Different abnormalities in behavior were observed in the exposed worms in comparison to control. But no behavioral changes were recorded in control. Control worms were active and alert to the slightest disturbance with their well synchronized clumping tendency. The effects of pesticide were observed as hyperactive movement (HM), clumping tendency (CT), mucus secretion (MS) and wrinkling activity (WE) are shown in Table 6. The clumping tendency of Tubifex tubifex was decreased with the increasing concentration of the test chemical and exposure time in comparison to control. The hyperactive movement of the worms increases with the increasing concentration of $\mathrm{ZnO}$ but decreases with exposure period. Mucous secretion and wrinkling effects of the worm were increased at $45 \mathrm{mg} / \mathrm{l}$ and above. The clumping tendency was gradually decreased with the increasing concentration of the toxicants and was absent at $75 \mathrm{mg} / \mathrm{l}$ and above irrespective of exposure times. But the rate of mucous secretion was very high at these concentrations.

\section{Discussion}

In the current study, $\mathrm{Zn}$ toxicity was indicated by Tubifex tubifex mortality. For any toxicological study, determination of the $\mathrm{LC}_{50}$ value is the initial step [31]. The present study illuminates the acute toxicity of $\mathrm{ZnO}$ on the benthic worm Tubifex tubifex. The result of the $96 \mathrm{~h} \mathrm{LC}_{50}$ value of $\mathrm{ZnO}$ was determined to be $11.15 \mathrm{mg} / \mathrm{l}$ using Finney's probit analysis method. This value is supported by the values obtained from Behrens-Karber's method (17.75 mg/l) and Miller and Tainter method (11.22 mg/l). Similar results were obtained by previous researchers during acute toxicity study of $\mathrm{Zn}$. The present $96 \mathrm{~h} \mathrm{LC}_{50}$ value $(11.15 \mathrm{mg} / \mathrm{l})$ of $\mathrm{Zn}$ to Tubifex tubifex is higher than the values obtained by earlier researchers in Oncorhynchus mykiss (0.95 and $3.79 \mathrm{mg} / \mathrm{l})$ [32, 33], Salmo gairdneri (0.55 mg/l, $0.24 \mathrm{mg} / \mathrm{l}$ and $4 \mathrm{mg} / \mathrm{l})$ [34, 35, 36], Hypophthalmichthys molitrix $(1.23 \quad \mathrm{mg} / \mathrm{l})$ and Ctenopharyngodon idella $(4.6 \mathrm{mg} / \mathrm{l})$ [8]. But it was slightly lower than the value found in Oncorhynchus mykiss $(12.88$ $\mathrm{mg} / \mathrm{l}$ ) [9], Oreochromis niloticus (63.98 mg/l) [31], Labeo rohita (65 mg/l) [37] and Channa punctatus (48.68 mg/l) [38]. This variation in toxicity of Zinc was probably due to the variation in physic-chemical properties of water [39], size, weight, age group and the habitat of the test organisms [40]. These kinetic variables play a vital role in the variation in $\mathrm{LC}_{50}$ values.

Behavioural changes signify an integrated response of test species to toxicant stress. Behaviour provides a unique perception among the body physiology and ecology of an organism and its environment. Similar kind of behavioural reactions were also observed in Branchiura sowerbyi exposed to alpha-cypermethrin and Triazophos [17, 23, 41]. With the increasing concentration of the toxicant and exposure time, the clumping tendency of the worm decreases. High amount of mucus secretion was recorded with the increase in exposure time. These abnormal ethological behaviours indicates towards the avoidance reaction of the worms towards toxicant. Previous researchers suggested that the metal effects the respiration of the worm by blocking the gas exchange through formation of mucus-metal complex over the body surface [42].

The result of the present acute toxicity study showed that Tubifex tubifexwas sensitive towards $\mathrm{Zn}$ toxicity. The obtained $96 \mathrm{~h} \mathrm{LC}_{50}$ value indicates that Zinc can affect the aquatic organisms and disrupt the natural aquatic food chain even at low concentration. The ethological changes due to Zinc toxicity may be used as a bio indicator for heavy metal toxicity studies.

Table 1: Mean values $( \pm \mathrm{SD})$ of $\%$ mortality of Tubifex tubifex exposed to different concentrations of $\mathrm{ZnO}$ at different times of exposure (24, 48, 72 and 96h). The mortality increases significantly with increasing concentration and time of exposure. Mean values within columns indicated by different superscript letters (a-j) and mean values within rows indicated by different superscript letters (m-p) are significantly different (2 way ANOVA followed by Tukey test).

\begin{tabular}{|c|c|c|c|c|}
\hline \multirow{2}{*}{$\begin{array}{c}\text { Concentrati } \\
\text { on } \\
(\mathrm{mg} / \mathrm{l})\end{array}$} & \multicolumn{4}{|c|}{ \% Mortality } \\
\hline & $24 \mathrm{~h}$ & $48 \mathrm{~h}$ & $72 \mathrm{~h}$ & 96h \\
\hline 0 (Control) & $0 \pm 0^{\mathrm{am}}$ & $0 \pm 0^{\mathrm{am}}$ & $0 \pm 0^{\mathrm{am}}$ & $0 \pm 0^{\mathrm{am}}$ \\
\hline 5 & $10 \pm 2.5^{\mathrm{bm}}$ & $20 \pm 4^{\mathrm{bn}}$ & $30 \pm 5^{\text {bo }}$ & $40 \pm 3^{\mathrm{bp}}$ \\
\hline 15 & $30 \pm 2^{\mathrm{cm}}$ & $30 \pm 3.5^{\mathrm{cm}}$ & $40 \pm 3.5^{\mathrm{cn}}$ & $50 \pm 3.5^{\mathrm{co}}$ \\
\hline 30 & $40 \pm 3.5^{\mathrm{dm}}$ & $50 \pm 4.5^{\mathrm{dn}}$ & $60 \pm 5^{\text {do }}$ & $60 \pm 4^{\mathrm{do}}$ \\
\hline 45 & $50 \pm 2^{\mathrm{em}}$ & $60 \pm 2^{\mathrm{en}}$ & $70 \pm 4.5^{\mathrm{eo}}$ & $80 \pm 3.5^{\mathrm{ep}}$ \\
\hline 60 & $70 \pm 4^{\mathrm{fm}}$ & $70 \pm 2.5^{\mathrm{fm}}$ & $\begin{array}{l}70 \pm \\
2.5^{\mathrm{em}}\end{array}$ & $80 \pm 4^{\text {en }}$ \\
\hline 75 & $70 \pm 3.5^{\mathrm{gm}}$ & $70 \pm 3^{\mathrm{fm}}$ & $80 \pm 3^{\mathrm{fn}}$ & $90 \pm 4.5^{\text {fo }}$ \\
\hline 90 & $80 \pm 5^{\mathrm{hm}}$ & $90 \pm 4^{\text {gn }}$ & $90 \pm 4^{\text {gn }}$ & $100 \pm 0^{\mathrm{go}}$ \\
\hline 100 & $90 \pm 3^{\mathrm{im}}$ & $90 \pm 2.5^{\mathrm{gm}}$ & $100 \pm 0^{\mathrm{hn}}$ & \\
\hline 120 & $90 \pm 3.5^{\mathrm{im}}$ & $100 \pm 0^{\mathrm{hn}}$ & & \\
\hline 140 & $100 \pm 0^{j}$ & & & \\
\hline
\end{tabular}




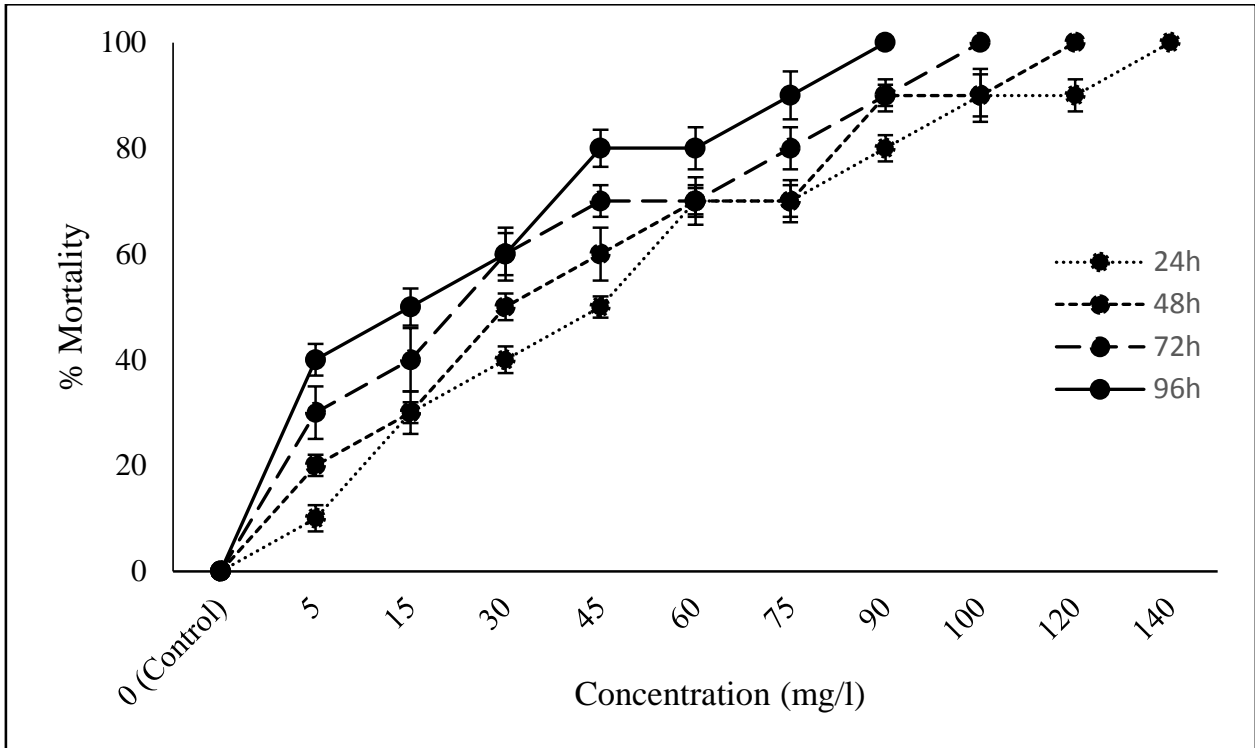

Figure 1: \% Mortality of Tubifex tubifex against different concentrations of ZnO during 96h of exposure. (p<0.05).
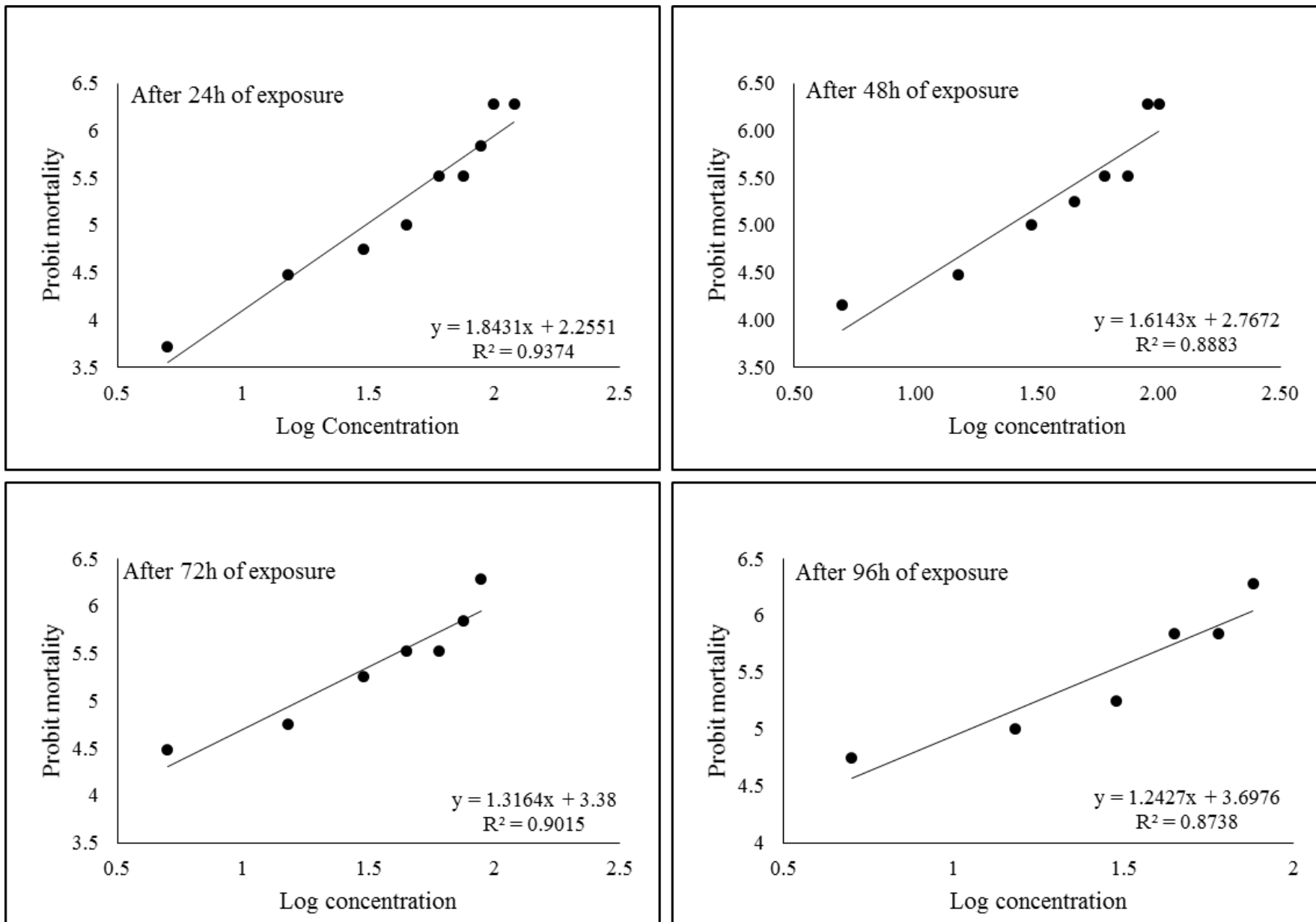

Figure 2:Probit mortality of Tubifex tubifex against different log concentrations of $\mathrm{ZnO}$ after 24, 48, 72 and 96 hof exposure. $(\mathrm{p}<0.05)$. 
Table 2: LC50 values (with 95\% confidence limits, regression equation, $\mathrm{R}^{2}$ and $\mathrm{r}$ values) of $\mathrm{ZnO}$ to the Tubifex tubifex at different times of exposure $(24,48,72$ and $96 \mathrm{~h})$

\begin{tabular}{|c|c|c|c|c|c|c|c|c|c|c|c|}
\hline \multirow[t]{3}{*}{ Hours } & \multicolumn{6}{|c|}{ Lethal Concentration Values (mg/l) } & \multicolumn{2}{|c|}{$\begin{array}{l}\text { 95\% Fiducial } \\
\text { Limits of } L_{50}\end{array}$} & \multirow{3}{*}{$\begin{array}{c}\text { Probit } \\
\text { Regression } \\
\text { Equation } \\
\text { Y=ax+b }\end{array}$} & \multirow[t]{3}{*}{$\mathbf{R}^{2}$ Value } & \multirow[t]{3}{*}{ r value } \\
\hline & \multirow[b]{2}{*}{ U్త } & \multirow[b]{2}{*}{$U^{\varrho}$} & \multirow[b]{2}{*}{$\bigcup_{-}^{\infty}$} & \multirow[b]{2}{*}{ 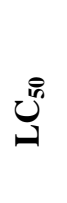 } & \multirow[b]{2}{*}{$\underbrace{i}_{1}$} & \multirow[b]{2}{*}{ ن্త } & & & & & \\
\hline & & & & & & & 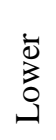 & 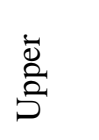 & & & \\
\hline $24 \mathrm{~h}$ & $\stackrel{8}{\stackrel{8}{-}}$ & $\ddot{0}$ & $\begin{array}{l}\infty \\
\infty \\
\qquad \\
\qquad\end{array}$ & $\begin{array}{l}\infty \\
\stackrel{\infty}{\infty} \\
\stackrel{\infty}{0}\end{array}$ & $\frac{n}{8}$ & $\begin{array}{l}\underset{f}{\stackrel{2}{n}} \\
\text { in }\end{array}$ & $\frac{\infty}{\stackrel{\infty}{\sim}}$ & $\underset{⿱ 亠 \infty}{\stackrel{\infty}{+}}$ & $\mathrm{Y}=1.84 \mathrm{x}+2.25$ & 0.94 & 0.96 \\
\hline $48 \mathrm{~h}$ & $\frac{2}{0}$ & $\begin{array}{l}\bar{\sigma} \\
\dot{n}\end{array}$ & $\begin{array}{l}\stackrel{\varrho}{\Xi} \\
=\end{array}$ & $\stackrel{n}{\stackrel{2}{2}}$ & in & $\stackrel{?}{\stackrel{f}{f}}$ & $\begin{array}{l}\infty \\
\stackrel{2}{2}\end{array}$ & 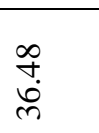 & $Y=1.61 x+2.76$ & 0.88 & 0.94 \\
\hline $72 \mathrm{~h}$ & 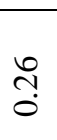 & $\stackrel{\Re}{\stackrel{2}{-}}$ & $\begin{array}{l}: \\
\stackrel{0}{0}\end{array}$ & $\mathscr{\hat { \sigma }}$ & $\underset{⿱ 亠 乂}{\dot{q}}$ & $\begin{array}{l} \pm \\
\stackrel{0}{0}\end{array}$ & $\begin{array}{l}\mathbb{O} \\
\stackrel{0}{0}\end{array}$ & $\begin{array}{l}\hat{\sigma} \\
\infty \\
\infty \\
i\end{array}$ & $\mathrm{Y}=1.32 \mathrm{x}+3.37$ & 0.90 & 0.94 \\
\hline $96 \mathrm{~h}$ & $\frac{ \pm}{0}$ & రㅜ. & 三 & $\stackrel{n}{\Xi}$ & $\begin{array}{l}\text { ì } \\
\text { ì }\end{array}$ & $\begin{array}{l}\vec{\exists} \\
\stackrel{\overbrace{}}{\Xi}\end{array}$ & $\begin{array}{l}0 \\
0 \\
6\end{array}$ & ஸे & $\mathrm{Y}=1.24 \mathrm{x}+3.69$ & 0.87 & 0.93 \\
\hline
\end{tabular}

Table 3:96h $\mathrm{LC}_{50}$ value according to the method of Miller and Tainter and Behrens-Karber's method

\begin{tabular}{|c|c|}
\hline \multicolumn{2}{|c|}{ 96h $\mathbf{L C}_{\mathbf{5 0}}$ value of $\mathbf{Z n O}$ according to } \\
\hline Miller and Tainter method & $11.22 \mathrm{mg} / \mathrm{l}$ \\
\hline Behrens-Karber's method & $17.75 \mathrm{mg} / \mathrm{l}$ \\
\hline
\end{tabular}

Table 4:Safe concentration range of $\mathrm{ZnO}$ based on the $96 \mathrm{hC}_{50}$ value

\begin{tabular}{|c|c|c|c|}
\hline Chemical & 96h LC50 & Method & Safe Value (mg/l) \\
\hline $\mathrm{ZnO}$ & $11.15 \mathrm{mg} / \mathrm{l}$ & Burdick & 1.11 \\
\cline { 3 - 4 } & & CWQC & 0.01115 \\
\cline { 3 - 4 } & & NAS/NAE & $1.11-0.0001115$ \\
\cline { 3 - 4 } & & IJC & 0.55 \\
\hline
\end{tabular}

Table 5: Maximum allowable concentration (MAC), the lowest observable effect concentration (LOEC) and no observable effect concentration (NOEC) values of $\mathrm{ZnO}$ to Tubifex tubifex

\begin{tabular}{|l|c|}
\hline Maximum allowable concentration (MAC) & $1.11 \mathrm{mg} / \mathrm{l}$ \\
\hline Lowest observable effect concentration (LOEC) & $2.1 \mathrm{mg} / \mathrm{l}$ \\
\hline No observable effect concentration (NOEC) & $1.3 \mathrm{mg} / \mathrm{l}$ \\
\hline
\end{tabular}


Table 6: Behavioural responses of Tubifex tubifex ( $\mathrm{CT}=$ Clumping Tendency, HM=Hyperactive Movement, MS= Mucous Secretion, -: absent, +: mild, ++: moderate, +++: high) exposed to different concentrations of $\mathrm{ZnO}$ at different times of exposure.

\begin{tabular}{|c|c|c|c|c|c|c|c|c|c|c|c|c|c|c|c|c|}
\hline \multicolumn{17}{|c|}{ Behavioural responses of Tubifex tubifex at different times of exposure } \\
\hline \multirow[t]{2}{*}{$\begin{array}{c}\text { Dose } \\
(\mathrm{mg} / \mathrm{l})\end{array}$} & \multicolumn{4}{|c|}{$\begin{array}{c}\text { Dose } \\
(\mathrm{mg} / \mathrm{l})\end{array}$} & \multicolumn{4}{|c|}{$\begin{array}{c}\text { Dose } \\
(\mathrm{mg} / \mathrm{l})\end{array}$} & \multicolumn{4}{|c|}{$\begin{array}{c}\text { Dose } \\
(\mathrm{mg} / \mathrm{l})\end{array}$} & \multicolumn{4}{|c|}{$\begin{array}{c}\text { Dose } \\
(\mathrm{mg} / \mathrm{l})\end{array}$} \\
\hline & $24 \mathrm{~h}$ & $48 \mathrm{~h}$ & $72 \mathrm{~h}$ & $96 \mathrm{~h}$ & $24 \mathrm{~h}$ & $48 \mathrm{~h}$ & $72 \mathrm{~h}$ & $96 \mathrm{~h}$ & $24 \mathrm{~h}$ & $48 \mathrm{~h}$ & $72 \mathrm{~h}$ & $96 \mathrm{~h}$ & $24 \mathrm{~h}$ & $48 \mathrm{~h}$ & $72 \mathrm{~h}$ & $96 \mathrm{~h}$ \\
\hline 5 & - & - & - & - & +++ & +++ & ++ & + & - & - & + & + & - & - & - & - \\
\hline 15 & + & + & - & - & ++ & ++ & + & + & - & - & + & + & + & - & - & - \\
\hline 30 & ++ & + & + & - & ++ & + & + & + & - & + & + & ++ & + & + & + & - \\
\hline 45 & ++ & ++ & + & + & + & + & - & - & + & ++ & ++ & ++ & ++ & + & + & + \\
\hline 75 & +++ & ++ & ++ & + & + & - & - & - & ++ & ++ & ++ & +++ & ++ & ++ & ++ & ++ \\
\hline 90 & +++ & ++ & ++ & + & - & - & - & - & ++ & ++ & ++ & +++ & +++ & +++ & ++ & ++ \\
\hline
\end{tabular}

\section{CONCLUSIONS}

The median lethal concentration of Zinc oxide to Tubifex tubifex was estimated in terms of $\mathrm{LC}_{50}$ values. The $24 \mathrm{~h}, 48 \mathrm{~h}$, $72 \mathrm{~h}$ and $96 \mathrm{~h} \mathrm{LC}_{50}$ value of Zinc oxide to Tubifex tubifex were $30.88,24.15,19.95$ and $11.15 \mathrm{mg} / \mathrm{l}$ respectively. It shows that Tubifex tubifex is very much sensitive toward toxicity of Zinc even presence in a minute quantities. Thus, it can be used as an excellent model organism to observe the potential hazards of acute exposure of the heavy metals to aquatic organisms. This study also shows the importance of behavioural parameter in assessing the hazards of the nondegradable heavy metals to aquatic organisms. This approach may help in the approximation of potential health hazards to non-target aquatic organisms upon exposure to Zinc.

\section{ACKNOWLEDGEMENT}

The authors are thankful to the Head, Department of Zoology, The University of Burdwan for providing infrastructural facilities and UGC-JRF fellowship (AC) for providing financial support to carry out the work.

\section{CONFLICT OF INTEREST}

The authors have no conflict of interest.

\section{REFERENCES}

[1] L.W. Gill, P. Ring, N.M. Higgins, P.M. Johnston, "Accumulation of heavy metals in a constructed wetland treating road runoff", Ecological engineering, Vol.70, pp.133139, 2014.

[2] M.S. Schuler, R.A. Relyea, "A review of the combined threats of road salts and heavy metals to freshwater systems", BioScience, Vol.68, Issue.5, pp.327-335, 2018.

[3] M. Bonsignore, D.S. Manta, S. Mirto, E.M. Quinci, F. Ape, V. Montalto, M. Gristina, A. Traina, M. Sprovieri,
"Bioaccumulation of heavy metals in fish, crustaceans, molluscs and echinoderms from the Tuscany coast", Ecotoxicology and environmental safety, Vol.162, pp.554$562,2018$.

[4] N.N. Sobihah, A.A. Zaharin, M.K. Nizam, L.L. Juen, K. Kyoung-Woong, "Bioaccumulation of heavy metals in maricultured fish, Lates calcarifer (Barramudi), Lutjanus campechanus (red snapper) and Lutjanus griseus (grey snapper)”, Chemosphere, Vol.197, pp.318-324, 2018.

[5] A. Ashraf, M. Javed, S. Abbas, "Investigation on the effects of zinc on gills peroxidase activity in the fish, Labeo rohita", JAPS, Journal of Animal and Plant Sciences, Vol.28, Issue.3, pp.951-955, 2018.

[6] L. Chupani, H. Niksirat, J. Velíšek, A. Stará, S. Hradilová, J. Kolařík, A. Panáček, E. Zusková, "Chronic dietary toxicity of zinc oxide nanoparticles in common carp (Cyprinuscarpio L.): tissue accumulation and physiological responses", Ecotoxicology and environmental safety, Vol.147, pp.110116, 2018.

[7] L.Han, Y. Zhai, Y. Liu, L. Hao, H. Guo, "Comparison of the in vitro and in vivo toxic effects of three sizes of zinc oxide $(\mathrm{ZnO})$ particles using flounder gill (fg) cells and zebrafish embryos", Journal of Ocean University of China, Vol.16, Issue.1, pp.93106, 2017.

[8] Z. Weiling, Y. Lin, X. Xuancheng, G. Shuchun, "Toxic effects of zinc on four species of freshwater fish", Chinese Journal of Oceanology and Limnology, Vol.9, Issue.1, pp.64-70, 1991.

[9] A. Gündoğdu, "Acute toxicity of zinc and copper for rainbow trout (Onchorhyncus mykiss)", Journal of FisheriesSciences.com, Vol.2, Issue.5, pp.711-720, 2008.

[10] G. Mance, "Pollution Threat of Heavy Metals in Aquatic Environments", Elsevier, London, PP.372, 1987.

[11] J.G. Hale, "Toxicity of metal mining wastes", Buletin Environmental Contamine Toxicology, Vol.17, pp.66-73, 1977.

[12] K. Dhara, D. Mukherjee, N.C. Saha, "Acute Toxicity of Cadmium to Benthic Oligochaete Worm, Branchiura sowerbyi Beddard, 1982 and Juvenile Catfish, Clarias batrachus 
Linnaeus, 1758”, Proceedings of the Zoological Society,.Springer India, Vol.68, Issue.2, pp.116-119, 2015.

[13] B.S. Khangarot, R.S. Rathore, D.M. Tripathi, "Effects of chromium on humoral and cell-mediated immune responses and host resistance to disease in a freshwater catfish, Saccobranchus fossilis (Bloch)", Ecotoxicology and Environmental Safety, Vol.43, Issue.1, pp.11-20, 1999.

[14] S. Bej, D. Mukherjee, N.C. Saha, "Acute toxicity of AlphaCypermethrin to oligochaete worm, Branchiurasowerbyi (Beddard 1982) along with their behavioural responses", International Journal of Scientific Research, Vol.4, Issue.12, pp.325-326, 2015.

[15] APHA, AWWA, WPCA, "Standard methods for the examination of water and wastewater 22 ed", American Public Health Association, Washington DC, 2012.

[16] Development. Environment Directorate, "The OECD Principles of Good Laboratory Practice (No. 45)”, Organisation for Economic Co-operation and Development, Environment Directorate, 1992.

[17] A. Kaviraj F. Bhunia N.C. Saha, "Toxicity of methanol to fish, crustacean, oligochaete worm, and aquatic ecosystem", International journal of toxicology, Vol.23, Issue.1, pp.55-63, 2004.

[18] APHA, "Standard Methods for the Examination of Water and Wastewater 20th Edition", Unite Book Press, Marylan, Unite States, 1998.

[19] S. Saha, N.C. Saha, D. Mukherjee, "Acute Toxicity and Behavioral Alterations of Oligochaete Worm, Branchiura sowerbyi Exposed to Diazinon", Research \& Reviews: A Journal of Life Sciences, Vol.8, Issue.2, pp.1-5, 2018.

[20] C. Sarkar, N.C. Saha, "Effects of a Pyrethroid insecticide Cypermethrin on benthic Oligochaete worm, Branchiura sowerbyi (Beddard, 1982)", Global Journal for Research Analysis, Vol.6, Issue.7, pp.499-500, 2017.

[21] N.C. Saha, S.K. Giri, N. Chatterjee, S.J. Biswas, S. Bej, "Acute Toxicity of Dichlorvos to Branchiura sowerbyi (Beddard, 1982)", Global Journal For Research Analysis, Vol.5, Issue.5, pp. 138-139, 2016.

[22] D. Mukherjee, N.C. Saha, "Acutetoxicity of 2, 4, 6trichlorophenol to copepod, Cyclops viridis and oligochaete worm, Branchiura sowerbyi", Environment and Ecology, Vol.30, Issue.3C, pp.65-70, 2012.

[23] S. Bej, D. Mukherjee, N.C. Saha, "Acute toxicity of AlphaCypermethrin to oligochaete worm, Branchiura sowerbyi (Beddard 1982) along with their behavioural responses", International Journal of Scientific Research, Vol.4, Issue.12, pp.325-326, 2015.

[24] D.J. Finney, “Probit analysis”, New York, Ny, 10022, PP.32, 1971.

[25] L.C. Miller, M. Tainter, "Estimation of the ED50 and its error by means of logarithmic-probit graph paper", Proceedings of the Society for Experimental Biology and Medicine, Vol.57, Issue.2, pp.261-264, 1944.
[26] C.D. Klassen, "Principles of toxicology. In: Gilman, A.G., Tall, T.W., Nies, A.S., Taylor, P. (Eds.)”, Pharmacology \& Therapeutics, Vol.8, pp.49-61, 1991.

[27] G.E. Burdick, "Use of bioassays in determining levels of toxic wastes harmful to aquatic organisms", American Fisheries Society, Special Publication, Vol.4, pp.7-12, 1967.

[28] International Joint Commission (IJC), "New and Revised Great Lakes Water Quality Objectives. Great lake basin, Windsor", IJC: Ottawa, ON, Canada, 1977.

[29] National Academy of Science/National Academy of Engineering (NAS/NAE), "Water quality criteria, EPA -R3033”, US Government Printing Office: Washington DC, USA, 1973.

[30] Committee on Water Quality Criteria, "A report of the committee on water quality and research series", US Environmental Protection Agency Report; Lincinnati, $\mathrm{OH}$, USA, 1972.

[31] M. Abdel-Tawwab, G.O. El-Sayed, S.H.H. Shady SHH, "Acute toxicity of water-born zinc in Nile tilapia, Oreochromis niloticus (L.) fingerlings", In Proceedings of the Ninth international Symposium on Tilapia in Aquaculture Shanghai, China, 2011.

[32] E. Bagdonas, M.Z. Vosylienè, "A study of toxicity and genotoxicity of pper, zinc and their mixture to rainbow trout (Oncorhynchus mykiss)”, B1ologija, Vol.1, pp.8-13, 2006.

[33] G. Svecevièrus, "Acute toxicity of zinc to common freshwater fishes of Lithuania”, Acta Zoologica Lituanica Hydrobiologia, Vol.9, Issue.2, pp.1392-1657, 1999.

[34] J.G. Hale, "Toxicity of metal mining wastes", Buletin Environmental Contamine Toxicology, Vol.17, pp.66-73, 1977.

[35] J.P. Goettl, P.H. Davies, J.R. Sinley, "Water pollution studies”, In: Colorado Fisheries Research Review, Vol.8, pp.68-75, 1976.

[36] V.M. Brown, R.A. Dalton, "The acute lethal toxicity to rainbow trout of mixtures of copper, phenol, zinc and nickel”, Journal of Fish Biology, Vol.2, pp.211-216, 1970.

[37] K.V. Bengeri, H.S. Patil, "Respiration, liver glycogen and bioaccumulation in Labeo rohita exposed to zinc", Indian Journal of Comparative Animal Physiology, Vol.4, Issue.2, pp.79-84, 1986.

[38] S.S. Murugan, R. Karuppasamy, K. Poongodi, S. Puvaneswari, "Bioaccumulation pattern of zinc in freshwater fish Channa punctatus (Bloch.) after chronic exposure”, Turkish Journal of Fisheries and Aquatic Sciences, Vol.8, Issue.1, pp.55-59, 2008.

[39] C.M. Wood, "Target organ toxicity in marine and freshwater teleosts", New Perspectives: Toxicology and the Environment, Vol.1, pp.1-89, 2001.

[40] K. Roy, D.K. Mandal, "Acute toxicity study and behavioural response of Indian minor carp Labeo bata by the exposure of nonylphenol ethoxylated", International Journal of Scientific Research in Biological Sciences, Vol.5, Issue.4, pp.55-60, 2018. 
[41] C. Sarkar, N.C. Saha, "A study on acute toxicity of an insecticide Triazophos on zooplankton Cyclops viridis (Jurine, 1820) along with the changes in their behaviour", Global Journal for Research Analysis, Vol.5, Issue.11, pp.240-241, 2016.

[42] L.S. Whitley, "The resistance of tubificid worms to three common pollutants", Hydrobiologia, Vol.32, pp.192-205, 1967.

\section{AUTHORS PROFILE}

Mr. Arnab Chatterjee pursued his M.Sc. degree from The University of Burdwan in the year 2016. He had qualified CSIR-UGC NET JRF (Dec, 2016), LS (Dec, 2017) and GATE (2017). He is currently working as a UGC-JRF in Fishery and Ecotoxicology Research Laboratory, Dept. of Zoology, The University

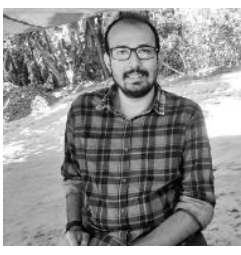
of Burdwan, under the supervision of Prof. Nimai Chandra Saha, Vice Chancellor, The University of Burdwan. He is working on the field of aquatic toxicology (effects of pesticides/heavy metals/surfactant on fish and their bioremediation).

Mr. Ritwick Bhattacharya pursued his M.Sc. degree from The University of Burdwan in the year 2014. He had qualified GATE and WBSET (2019) and currently working as a state funded fellow in Fishery and Ecotoxicology Research Laboratory, Dept. of Zoology, The University of Burdwan, under

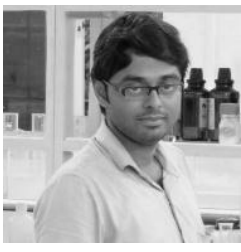
the supervision of Prof. Nimai Chandra Saha, Vice Chancellor, The University of Burdwan. $\mathrm{He}$ is working on the field of aquatic toxicology and ecotoxicology.

Prof. Nimai Chandra Saha is currently working as Vice Chancellor, The University of Burdwan. He had pursued his Ph.D. from Kalyani University. He has more than 30 years of teaching (both UG and PG) and research experience. He has published more than 70

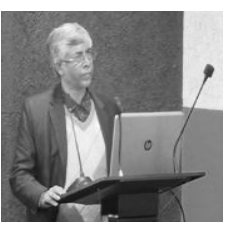
research and review articles in reputed national and international journals. He is working in the field of fishery science, aquatic toxicology, ecology \& environment and fish breeding. 